\title{
Departments of Pediatrics Approach at the Beginning of the COVID-19 Pandemic
}

\author{
Beatriz Simões Vala ${ }^{a, b}$ Mariana Lopes Costa ${ }^{a, b}$ Joana Aquino ${ }^{a, b}$ \\ Bilhota Xavier ${ }^{\mathrm{b}}$ \\ ${ }^{a}$ Department of Pediatrics, Centro Hospitalar de Leiria, Leiria, Portugal; ${ }^{b}$ Pediatric Society of Quality and Safety \\ (SPEQS), Lisboa, Portugal
}

\section{Keywords}

Child · COVID-19 · Health planning · Pandemic · Portugal ·

Quality in healthcare

\begin{abstract}
Introduction: The novel coronavirus pandemic poses a challenge to healthcare systems' balance. Since children apparently have milder disease courses, COVID-19 guidelines were not easily adapted to pediatrics. We intend to characterize how the national departments of pediatrics adapted to the pandemic at the beginning and describe the measures that were taken to protect healthcare workers. Methods: An unvalidated online questionnaire was sent to all departments of pediatrics directors of Portuguese public health system hospitals regarding course of actions taken between April and May 2020 to face the new coronavirus pandemic. Neonatology units were excluded. Results: Thirty-eight questionnaires were included (93\% of public health system departments). All departments divided the pediatric emergency unit into non-COVID-19 and COVID-19 areas: $68 \%$ in different areas, $47 \%$ divided the same space with a physical barrier and $16 \%$ with a line on the floor. Healthcare workers
\end{abstract}

were divided into non-COVID-19 and COVID-19 teams in $71 \%$ of the departments. Personal protective equipment mostly used in COVID-19 areas consisted of face shield/goggles (97\%) and respirators (95\%). Others wore surgical masks (8\%). The main clinical criteria for testing were Direção-Geral da Saúde criteria (84\%). Presential appointments were maintained in $68 \%$ of departments with selected follow-up (81\%) and priority-first appointments (73\%). Discussion: National departments of pediatrics faced the pandemic differently and measures taken in the emergency department were more similar. Personal protective equipment was adequate in all wards with occasional overuse, considering national and international guidelines.

$$
\begin{aligned}
& \text { (c) } 2021 \text { The Author(s). Published by S. Karger AG, Basel } \\
& \text { on behalf of NOVA National School of Public Health }
\end{aligned}
$$

\section{Atuação dos serviços de Pediatria no início da pandemia COVID-19}

Palavras Chave

Criança · COVID-19 · Pandemia · Planeamento em saúde . Portugal · Qualidade nos cuidados de saúde (c) 2021 The Author(s). Published by S. Karger AG, Basel on behalf of NOVA National School of Public Health

This is an Open Access article licensed under the Creative Commons Attribution-NonCommercial-4.0 International License (CC BY-NC) (http://www.karger.com/Services/OpenAccessLicense), applicable to the online version of the article only. Usage and distribution for commercial purposes requires written permission.
Correspondence to:

Beatriz Simões Vala, beatriz.vala@ chleiria.min-saude.pt 


\section{Resumo}

Introdução: A pandemia COVID-19 constitui um desafio para os sistemas de saúde. Em Pediatria a morbimortalidade da doença é menor e as linhas de orientação não foram fáceis de adaptar. Pretendemos caracterizar a organização dos serviços de Pediatria nacionais no início da pandemia e as medidas tomadas para proteger os profissionais de saúde. Métodos: Elaboração de um questionário não validado sobre as medidas tomadas de abril a maio de 2020, enviado aos Diretores dos Serviços de Pediatria do Serviço Nacional de Saúde (SNS). As unidades de Neonatologia foram excluídas. Resultados: Incluímos 38 questionários (93\% dos Serviços do SNS). Todos os serviços dividiram a urgência pediátrica em áreas COVID-19 e não-COVID-19: 68\% em áreas distintas, 47\% dividiram o mesmo espaço fisicamente e 16\% com linha no chão. Os profissionais foram divididos em equipas COVID-19 e nãoCOVID-19 em 71\% dos serviços. Os equipamentos de proteção individual mais usados nas áreas COVID-19 foram viseira / óculos (97\%) e respiradores (95\%). Outros usaram máscara cirúrgica (8\%). Os critérios clínicos da DireçãoGeral da Saúde foram os mais usados para testar (84\%). As consultas presenciais mantiveram-se em $68 \%$ dos serviços, com consultas de seguimento selecionadas (81\%) e primeiras consultas prioritárias (73\%). Discussão: Os serviços de Pediatria adaptaram-se de forma diferente à pandemia, tendo-se verificado uma maior uniformização de atitudes a nível da urgência. O equipamento de proteção foi adequado em todas as áreas e ocasionalmente foram utilizados mais componentes que os recomendados nacional e internacionalmente.

(c) 2021 The Author(s). Published by S. Karger AG, Basel on behalf of NOVA National School of Public Health

\section{Introduction}

Coronavirus disease-2019 (COVID-19) was first reported in December 2019 in Wuhan, China, and rapidly spread worldwide causing the second pandemic of this century, after the 2009 H1N1 pandemic [1, 2]. Worldwide data points to rates higher than $90 \%$ of asymptomatic children or children with mild to moderate disease symptoms, and the death rate is lower in children when compared to adults and elderly $[1,3]$. It is still unknown if there are long-term effects of SARS-CoV-2 infection, even in milder cases.

In Portugal, the first pediatric case was reported on March 7, 2020, and by the end of May, a total of 1,771 cases between 0 and 19 years of age were reported [4]. Between April and May 2020, cases below 19 years old ac- counted for $6.2 \%$ of total cases, and there were no casualties in this age group [4].

Due to little and inconsistent knowledge about COVID-19 in children, national and international guidelines were not easily adapted to departments of pediatrics, leading to an increased constraint on healthcare systems and their workers.

Protecting healthcare workers (HCW) from contracting SARS-CoV-2 should be a main priority to protect and keep healthcare systems working. Understanding the modes of transmission is essential to adopt the right preventive measures. SARS-CoV-2 is primarily transmitted person-toperson through respiratory droplets containing the virus and through close contact $[3,5]$. Airborne transmission is possible when aerosol-generating procedures are performed, but it is not yet known if in their absence this transmission can still happen [5]. Knowledge of these data and the uncertainty of what is yet to be known generates inconsistencies regarding personal protective equipment (PPE) recommendations [5]. Control measures start long before a suspected patient reaches an HCW. Source control, triage systems to identify suspected patients, and course of actions to minimize contact with COVID-19 patients are the general lines of implemented measures in healthcare systems worldwide [5]. Correct PPE use is an important line of defense for HCW in the observation and treatment of suspected COVID-19 patients [5].

Our study aims to characterize how Portuguese National Health System Departments of Pediatrics have adapted to the pandemic and what measures were taken to best protect their HCW during the beginning of the pandemic, in April and May 2020.

\section{Materials and Methods}

\section{Study Sample, Period, and Design}

To evaluate how national departments of pediatrics adapted to the COVID-19 pandemic between April and May 2020, a descriptive study was implemented using an unvalidated, anonymous questionnaire based on COVID-19 national guidelines and orientations. It consisted of 47 questions, of which 19 were dichotomous questions, 17 multiple-choice questions, 10 text numeric questions, and one single row text questions. The questionnaire was sent by e-mail to all National Health System Departments of Pediatrics directors. Data regarding neonatology units were excluded.

\section{Data Collection and Analysis}

The questionnaire assessed departments' demographic characteristics, such as region, hospital's typology, and possessing an intensive care unit. Departments of pediatrics directors were then asked about emergency ward (EW) re-organization (physical space and HCW teams), the PPE used in the EW, appointments, 
Table 1. Characterization of departments of pediatrics in Portuguese National Health System hospitals in response to the COVID-19 pandemic

\begin{tabular}{|c|c|c|}
\hline Region & $\begin{array}{l}\text { South } \\
\text { North } \\
\text { Centre } \\
\text { Islands (Azores, Madeira) } \\
\text { No reply }\end{array}$ & $\begin{array}{l}15(40) \\
10(26) \\
9(24) \\
3(8) \\
1(2)\end{array}$ \\
\hline \multicolumn{2}{|c|}{ Hospitals with intensive care unit } & $8(22)$ \\
\hline \multicolumn{2}{|c|}{ EW separation in non-COVID-19 and COVID-19 areas } & $38(100)$ \\
\hline EW separation & $\begin{array}{l}\text { Different areas } \\
\text { Physical separation in the same area } \\
\text { Separation with a line on the floor }\end{array}$ & $\begin{array}{l}26(68) \\
18(47) \\
6(16)\end{array}$ \\
\hline \multicolumn{2}{|c|}{ EW teams for non-COVID-19 and COVID-19 areas } & $27(71)$ \\
\hline \multicolumn{2}{|c|}{ Mirror teams (presential and nonpresential schedule) } & $26(68)$ \\
\hline \multicolumn{2}{|l|}{ Rotative teams } & $23(61)$ \\
\hline Rotation & $\begin{array}{l}\text { Weekly } \\
\text { Every } 2 \text { weeks } \\
\text { Every } 3 \text { weeks } \\
\text { Each } 3 \text { or } 4 \text { days } \\
\text { NS }\end{array}$ & $\begin{array}{l}14(61) \\
4(17) \\
1(4) \\
2(9) \\
2(9)\end{array}$ \\
\hline \multicolumn{2}{|c|}{ SARS-CoV-2 test before elective surgery } & $34(92)$ \\
\hline \multicolumn{2}{|c|}{ Test for the caregiver of the former } & $24(67)$ \\
\hline \multicolumn{2}{|c|}{ SARS-CoV-2 test before day hospital intervention } & $12(32)$ \\
\hline \multicolumn{2}{|c|}{ Test for the caregiver of the former } & $8(24)$ \\
\hline \multicolumn{2}{|l|}{ Presential appointments } & $26(68)$ \\
\hline Which appointments & $\begin{array}{l}\text { Selected follow-up } \\
\text { Priority first } \\
\text { All first }\end{array}$ & $\begin{array}{l}22(81) \\
19(73) \\
5(19)\end{array}$ \\
\hline \multicolumn{2}{|c|}{ Room disinfection between appointments } & $23(72)$ \\
\hline Product used & $\begin{array}{l}\text { Alcohol } \\
\text { Bleach } \\
\text { Alcohol-based antiseptic solutions } \\
\text { Triclosan } \\
\text { Other NS }\end{array}$ & $\begin{array}{l}7(33) \\
6(29) \\
2(10) \\
1(5) \\
5(10)\end{array}$ \\
\hline
\end{tabular}

Values are $n$ (\%). COVID-19, coronavirus disease-2019; EW, emergency ward; NS, nonspecified. and how many HCW were tested and were found to be positive. Criteria and methods used for testing were asked for.

All answered questionnaires were included in the analysis if submitted until June 30,2020, and were excluded if they had more than $50 \%$ of unanswered questions.

All data are presented as means and standard deviations, or medians and 25th-75th percentiles, according to the variables' distribution. The descriptive statistic was performed using IBM SPSS $^{\circledR}$ Statistics for Windows, version 26.0.

\section{Ethics Questionnaire}

The questionnaire used in this study was developed based on national directives and guidelines regarding COVID-19 infection.
Participants were informed about the study aims through e-mail. Participation was voluntary and anonymous. The survey was sent by e-mail (a link for the anonymous questionnaire) to all Portuguese departments of pediatrics directors, and consent was assumed when an answered questionnaire was obtained.

\section{Results}

In this study, we included 38 questionnaires, representing 93\% of the National Health System Departments of Pediatrics. In the studied months, EWs were divided
90

Port J Public Health 2021;39:88-94 DOI: $10.1159 / 000519499$
Vala/Costa/Aquino/Xavier 
Table 2. Healthcare workers tested and personal protective equipment used in different contexts

\begin{tabular}{|c|c|c|c|}
\hline \multicolumn{3}{|c|}{ Departments with HCW tested } & $32(86)$ \\
\hline \multirow[t]{3}{*}{ Criteria to test } & \multicolumn{2}{|l|}{ Symptomatic } & $21(57)$ \\
\hline & \multicolumn{2}{|c|}{ With a positive contact } & $17(46)$ \\
\hline & \multicolumn{2}{|l|}{ All HCW } & $5(14)$ \\
\hline \multicolumn{3}{|l|}{ Total HCW tested } & 1,565 \\
\hline \multicolumn{3}{|c|}{ Total HCW with positive test } & $66(4)$ \\
\hline \multirow[t]{4}{*}{ HCW with positive test } & \multicolumn{2}{|l|}{ Doctors } & $25(38)$ \\
\hline & \multicolumn{2}{|l|}{ Nurses } & $22(33)$ \\
\hline & \multicolumn{2}{|l|}{ Technical assistants } & $10(15)$ \\
\hline & \multicolumn{2}{|c|}{ Operational assistants } & $9(14)$ \\
\hline PPE used for ... & ... suspected cases & ... nonsuspected cases & ... appointments \\
\hline Scrubs & $22(58)$ & $26(70)$ & $18(58)$ \\
\hline Fluid-resistant gown & $30(79)$ & $15(41)$ & $12(39)$ \\
\hline Coverall suit & $19(50)$ & - & - \\
\hline Face shield/goggles & $37(97)$ & $21(57)$ & $18(58)$ \\
\hline Surgical mask & $3(8)$ & $25(68)$ & $23(74)$ \\
\hline Respirators & $36(95)$ & $14(38)$ & $11(35)$ \\
\hline Hood cap & $20(53)$ & $1(3)$ & - \\
\hline Bouffant cap & $34(90)$ & $11(30)$ & $3(10)$ \\
\hline Long-sleeved gloves & $27(71)$ & $2(5)$ & $2(6)$ \\
\hline Short-sleeved gloves & $25(66)$ & $17(46)$ & $11(35)$ \\
\hline Shoe covers & $36(95)$ & $3(8)$ & $1(3)$ \\
\hline
\end{tabular}

Values are $n(\%) . \mathrm{HCW}$, healthcare workers; PPE, personal protective equipment.

into non-COVID-19 and COVID-19 areas in all hospitals: $68 \%$ rearranged the space in 2 separated areas, $47 \%$ created a physical division of the same space, and $16 \%$ drew a line on the floor. Ten departments (26\%) changed the way of division during the study period, 4 between the physical barrier and line on the floor (11\%), the other 4 between 2 separated areas and a physical barrier (11\%), and 2 changed among the 3 options (5\%). Medical staff constituted different teams responsible for each area in $71 \%$ of the hospitals, in which $68 \%$ had a presential and nonpresential schedule (mirror teams) and $61 \%$ had rotative teams. All children submitted to an elective surgery were tested previously, and in $32 \%$ of the hospitals, children checked at outpatient clinic care were also tested. Presential appointments were carried out in $68 \%$ of the surveyed departments, mainly including selected followup and priority-first appointments (Table 1).

In $86 \%(n=32)$ of the hospitals, HCW were tested, $57 \%$ for presenting symptoms and $46 \%$ for being contacts of confirmed cases. In none of the departments, tests were performed routinely in all HCW. Among a total of 1,565 professionals, 66 were positive for SARS-CoV-2 (repre- senting $4 \%$ of the reported HCW tested), 25 doctors and 22 nurses.

Table 2 shows the PPE used for different contexts: face shield/goggles were used by professionals in $97 \%$ of the hospitals and respirators in $95 \%$ for the observation of suspected cases. Long-sleeved (71\%) and short-sleeved gloves $(66 \%)$ were also used for suspect patients. Scrubs and surgical masks were used in $70 \%$ of departments of pediatrics to exam nonsuspect cases in the EW. PPE used for children's appointments were similar to the ones used for the observation of nonsuspected cases in the EW: surgical mask in 74 and $68 \%$, and face shield/goggles in 58 and $57 \%$ of hospitals, respectively. PPE used for suspected cases was the same for all ages in all hospitals; however, for the observation of nonsuspected children, there were differences in PPE choice according to age in $8 \%$ of the hospitals.

In Table 3, we present the criteria used for testing, with $84 \%$ of hospitals applying Direção-Geral da Saúde (DGS) criteria (fever $\geq 38.0^{\circ} \mathrm{C}$ or cough or difficulty to breathe/ dyspnea); $82 \%$ tested if the children had had contact with a confirmed positive case. The most frequently used cri- 
Table 3. Procedures for testing and associated characteristics

\begin{tabular}{lll}
\hline Criteria for testing & Hospitalization & $36(95)$ \\
& DGS* & $32(84)$ \\
& Contact with a positive case & $31(82)$ \\
& Comorbidity of child & $10(26)$ \\
& Comorbidity of cohabitant & $8(21)$ \\
& Newborn & $8(21)$ \\
& Elective/requested by another hospital & $3(8)$ \\
& Epidemic context & $2(5)$ \\
& Gastrointestinal symptoms & $2(5)$ \\
\hline Testing for non-COVID-19 hospitalization & $34(90)$ \\
\hline Caregiver of the former & & $25(66)$ \\
\hline Suspected cases tested in hospital & $29(76)$ \\
\hline Pediatric swabs & & $22(58)$ \\
\hline Mean time to results & $24-48 \mathrm{~h}$ & $20(53)$ \\
& $<24 \mathrm{~h}$ & $18(47)$ \\
\hline
\end{tabular}

Values are $n$ (\%). COVID-19, coronavirus disease-2019; DGS, Direção-Geral da Saúde. * DGS criteria: the presence of at least one of the following: fever (body temperature $\geq 38.0^{\circ}$ C) or cough or difficulty to breathe/dyspnea. terion for testing suspected children was hospitalization in $95 \%$. If nonsuspected children needed hospitalization, $90 \%$ of hospitals tested them and $66 \%$ tested their caregivers. Seventy-six percent tested children in the hospital, regardless of age, and the other hospitals referred them to community COVID-19-dedicated areas to perform the test.

Pediatric swabs were used in $58 \%$ of the hospitals and the results were available in less than $24 \mathrm{~h}$ in $47 \%$. Ten hospitals (27\%) transferred 69 positive children to another department of pediatrics: $30 \%$ were $1-5$ years old, $23 \%$ were $10-18$ years old, and $7 \%$ were newborns.

\section{Discussion}

The value and importance of infection prevention and control measures were proved during the SARS-CoV-2 pandemic. The need to protect HCW to prevent health services from collapse led to reorganization and exceptional procedures in departments of pediatrics.

By the end of March 2020, the DGS advised health institutions to take measures to minimize the spread of infection and instructions for use of PPE [6]. Those included reductions of presential appointments, setup of circuits to divide COVID-19 suspects from non-COVID-19 patients, and restraining the number of $\mathrm{HCW}$ in contact with SARS-CoV-2-confirmed patients [6]. All national departments of pediatrics divided the EW into non-COVID-19 and COVID-19 areas, but in different ways; about two-thirds (68\%) of hospitals used different areas, around half of them (47\%) divided the same space with a physical barrier and $16 \%$ with a line on the floor, while 10 changed the mode of division during the study time. As we understand it, these different adaptations were due to space and material available in each department. Unfortunately, no record of which adaptation was done first was made. Future studies should examine how patients were divided before and during EW triage and how waiting rooms were organized. The majority of those who responded also created non-COVID-19 and COVID-19 teams (71\%) and mirror teams (68\%). Besides diminishing contact between HCW and consequently constraining infection, these decisions also allowed the protection of risk groups among HCW.

To minimize HCW s' risk of exposure to the new coronavirus, PPE must be used as recommended and correct donning and doffing is essential to prevent SARS-CoV-2 infection. Based on the currently known modes of transmission of SARS-CoV-2, national and international authorities issued PPE recommendations when in contact with confirmed or suspected COVID-19 patients $[5,6]$. Surgical masks and eye protection are recommended for droplet safety [5]. If aerosol generation procedures are made, respirators must be used instead of surgical masks [5]. On the other hand, contact precaution is based on the
Vala/Costa/Aquino/Xavier 
use of water-resistant gowns and gloves [5]. Several international guidelines and reviews state that fluid-resistant gowns, gloves, respirators, and goggles or face shields are the adequate PPE to use when suspected COVID-19 patients are observed in the EW [7]. DGS guidelines during the study period added the use of shoe covers and hood caps and stated that bouffant caps should only be used when high-risk procedures (tracheal intubation, tracheostomy, and bronchoscopy) are performed [6]. The majority of those who responded confirmed that in their department HCW used respirators, face shield or goggles, shoe covers, bouffant caps, and fluid-resistant gowns when in contact with suspected COVID-19 cases (Table 3 ). In just one department the use of gloves (long- or short-sleeved) was not reported as part of PPE used in suspected COVID-19 cases. With these results, we can assume that most departments protected their HCW from droplet and contact transmission but with different components. Regarding nonsuspected cases, the DGS advised using a surgical mask, and apron and gloves if organic fluid contact was predicted [6]. Except for scrubs, the surgical mask was the most frequently used component $(68 \%)$, but others were used in different percentages and without concordance among departments. The lack of certainty concerning the mode of transmission of SARS-CoV-2 and the fear HCW have of becoming infected and spreading the disease through close relatives are some of the possible explanations of the apparent excessive use of PPE in these settings. DGS recommendations do not differentiate between the protections to be used by HCW in contact with suspected children irrespective of the age group. We suggest that further research should be undertaken to establish if any difference exists in national departments.

DGS guidelines regarding suspected HCW state that SARS-CoV-2 testing should be performed if an exposed HCW develops symptoms [8]. One half of those surveyed reported that HCW were tested because they were symptomatic $(57 \%)$ or had contact with SARS-CoV-2-positive cases (46\%). Regular testing of HCW was not performed. The option to do so could have identified infected cases at an early stage, avoiding possible in-hospital outbreaks. It was not asked in what circumstances contact with a SARS-CoV-2-positive case occurred (in a personal or professional context) or if in the professional context PPE was used correctly. We suggest that further research should be undertaken regarding nosocomial infection and in-hospital outbreaks, so that a better understanding regarding the protective measures taken can be reached and they can be reduced.

Departments of Pediatrics Approach in COVID-19 Pandemic
Since the COVID-19 pandemic declaration, Portuguese diagnostic criteria have been regularly revised, although our health authorities do not distinguish between criteria for children and adults. At first, epidemiologic and clinical criteria were used to consider a suspected case and testing was only done after a call to a physician support line (Linha de Apoio ao Médico) to validate the case as a suspect [9]. By March 23, 2020, the DGS stated that anyone with cough, fever, and/or dyspnea was considered suspect and should be tested [10]. Hospitalization was the most frequently reported criterion for testing (95\% with symptoms of COVID-19 and 90\% non-COVID-19 patients). Most departments also tested according to DGS criteria (84\%) and when there was contact with a positive case $(82 \%)$.

There are some singularities in pediatrics, namely the need for caregiver support during a child's hospitalization. This raised questions about the need to test caregivers. Although most departments tested children without COVID-19 symptoms when hospitalized, only two-thirds tested their caregivers. A consensual approach regarding testing children before elective surgery and non-COVID-19 hospital admissions is of note, but less than half performed the SARS-CoV-2 test before outpatient clinic care. Our results also show that in the study period, most departments' test results were available after $24 \mathrm{~h}$ and almost half did not have pediatric swabs - two aspects needing improvement, which we believe have already been overcome in the meantime.

More than two-thirds of departments (68\%) maintained presential appointments, most of all selected follow-up and/or priority-first appointments. Telephone consultations could have been a form used to maintain assistance activity in most departments, a way not only to adhere to children's and adolescent's follow-up, but also to prevent SARS-CoV-2 spread $[6,11]$. Regarding PPE use in appointments, the DGS states that nonsuspected patients should be observed with surgical masks and, if fluid contact is expected, gloves and a fluid-resistant apron [6]. Even though those interviewed reported high use of surgical masks (74\%) or respirators (35\%), the use of other PPE reported was not in line with these guidelines, with more than half using face shields or goggles.

The main limitations of this study come from its being an online questionnaire. Besides the possible different ways of analyzing and interpreting the questions, we also had some questions that were left unanswered and did not permit further analysis of other topics. Our questions were mostly dichotomous and multiple-answer and, after analyzing data, some of them deserved a fuller answer. 
National Health System Departments of Pediatrics faced the pandemic differently and measures taken in the EW were the most consistent. When setting COVID-19 and non-COVID-19 circuits in the EW, ideally these should be done using different areas to minimize contact between the suspected and nonsuspected cases. The lack of material and infrastructure to create adequate division is an obstacle, reflected in $26 \%$ of departments who changed the way of division during the 2 months of the study. It would be of value to create plans of action for future infectious diseases like COVID-19, where the need for space and HCW division should be included, showing what we are learning from this pandemic.

We advocate the conception of national Pediatric guidelines for the approach of suspected children with the reminder that new evidence is being released constantly and the update of guidelines should also be a priority. Regarding PPE, adequate use was reported in all settings and even with more components than those described as needed by national and international guidelines. Resources should be secured to protect HCW.

\section{Acknowledgement}

The authors thank all the departments who answered the questionnaire, allowing this work to be written.

\section{Statement of Ethics}

The authors declare that they complied with ethical principles according to the Declaration of Helsinki. Any opinions, findings, conclusions, or recommendations expressed in this article are those of the authors.

\section{Conflict of Interest Statement}

The authors have no conflicts of interest to declare.

\section{Funding Sources}

The research was developed without any funding.

\section{Author Contributions}

B.S.V. did the bibliographical search, analysis of the results, and drafting of the article. M.L.C. carried out the statistical analysis of the data and drafting of the article. J.A. collaborated with the analysis and interpretation of the results and critical review of the content of the article. B.X. supervised all aspects of this work. All authors contributed to the study design and proofreading of the manuscript.

\section{References}

1 Balasubramanian S, Rao NM, Goenka A, Roderick M, Ramanan AV. Coronavirus disease 2019 (COVID-19) in children: what we know so far and what we do not. Indian Pediatr. 2020 May;57(5):435-42.

2 Trippella G, Ciarcià M, Ferrari M, Buzzatti C, Maccora I, Azzari C, et al. COVID-19 in pregnant women and neonates: a systematic review of the literature with quality assessment of the studies. Pathogens. 2020 Jun;9(6):485509.

3 Pavone P, Ceccarelli M, Taibi R, La Rocca G, Nunnari G. Outbreak of COVID-19 infection in children: fear and serenity. Eur Rev Med Pharmacol Sci. 2020 Apr;24(8):4572-5.

4 Portugal. Ministério da Saúde. Direção-Geral da Saúde. Relatório de situação: COVID-19 [Internet]. Lisboa: DGS; 2020 [cited 11 Aug 2020]. Available from: https://covid19.minsaude.pt/relatorio-de-situacao/

5 Park SH. Personal protective equipment for healthcare workers during the COVID-19 pandemic. Infect Chemother. 2020 Jun;52(2):165-82.
6 Portugal. Ministério da Saúde. Direção-Geral da Saúde. Programa Nacional de Prevenção e Controlo de Infeções e das Resistências aos Antimicrobianos. Orientação DGS $\mathrm{n}^{\circ}$ 007/2020: prevenção e controlo de infeção por SARS-CoV-2 (COVID-19): Equipamentos de Proteção Individual (EPI) [Internet]. Lisboa: DGS; 2020 [cited 11 Aug 2020]. Available from: https://www.dgs.pt/directrizes-dadgs/normas-e-circulares-normativas/norman-0072020-de-29032020.aspx

7 Zimmermann P, Curtis N. Coronavirus infections in children including COVID-19. Pediatr Infect Dis J. 2020 May;39(5):355-68.

8 Portugal. Ministério da Saúde. Direção-Geral da Saúde. Orientação DGS no 013/2020: profissionais de saúde com exposição a SARSCoV-2 (COVID-19) [Internet]. Lisboa: DGS; 2020 [cited 15 Aug 2020]. Available from: https://www.dgs.pt/directrizes-da-dgs/orientacoes-e-circulares-informativas/orientacaon-0132020-de-21032020.aspx
9 Portugal. Ministério da Saúde. DireçãoGeral da Saúde. Orientação DGS no 002/2020: infeção pelo novo coronavírus (2019-nCoV) [Internet]. Lisboa: DGS; 2020 [cited 9 Aug 2020]. Available from: https:// www.dgs.pt/directrizes-da-dgs/orientacoes-e-circulares-informativas/orientacaon-0022020-de-25012020.aspx

10 Portugal. Ministério da Saúde. Direção-Geral da Saúde. Norma DGS no 004/2020: COVID-19: fase de mitigação: abordagem do doente com suspeita ou infeção por SARSCoV-2 [Internet]. Lisboa: DGS; 2020 [cited 15 Aug 2020]. Available from: https://www.dgs. $\mathrm{pt} /$ directrizes-da-dgs/normas-e-circularesnormativas/norma-n-0042020-de-23032020pdf.aspx

11 Turer RW, Jones I, Rosenbloom ST, Slovis C, Ward MJ. Electronic personal protective equipment: A strategy to protect emergency department providers in the age of $\mathrm{CO}$ VID-19. J Am Med Inform Assoc. 2020 Jun;27(6):967-71. 